Vol. 8, Issue 8, August 2021

DOI: $10.17148 /$ IARJSET.2021.8838

\title{
Employee engagement towards frontline employees relating to the current Covid - 19
}

\author{
Mrs.R.T.Induji ${ }^{1}$, Dr.K.Meenatchi Somasundari ${ }^{2}$
}

${ }^{1}$ Assistant Professor, Department of Management, Sri Krishna Arts and Science College, Coimbatore, Tamilnadu

${ }^{2}$ Assistant Professor, Department of Management, Sri Krishna Arts and Science College, Coimbatore, Tamilnadu

\begin{abstract}
Frontline employees are the cornerstone for the success of any organization. They work in frontline rather than operating in office. Employees who directly interact with customers are called frontline employees. Frontline employees contribute roughly about $70 \%$ of the global workforce. They include healthcare worker, service providers, sanitation teams, Volunteers etc. The study aims to identify the ways to engage frontline employees and the benefits gained from engaging frontline employees during Covid -19. Sample size identified for the study was 60 frontline employees. Statistical tools used for the analysis was descriptive analysis, ANOVA. Both primary and secondary data was used to collect the information. Snowball sampling method was adopted for the study.
\end{abstract}

Keywords: employee engagement, frontline employees, workforce, Covid -19

\section{OBJECTIVES OF THE STUDY:}

1. To find the ways to engage frontline employees during Covid -19

2. To know the benefits in engaging frontline employees during Covid - 19

3. To suggest the ways in improving engagement among frontline employees during Covid -19 .

\section{RESEARCH METHODOLOGY:}

Descriptive research design was adopted. The sampling method adopted for the study was snowball random sampling method. Both primary and secondary data collection method was used in the study. Sample size is 60 .

\section{ANALYSIS AND RESULTS:}

Demographic Analysis:

Platform the employees work:

\begin{tabular}{|l|l|l|}
\hline Sl.No. & Platform & Percentage \\
\hline 1 & Healthcare worker & $30 \%$ \\
\hline 2 & Essential service providers & $21 \%$ \\
\hline 3 & sanitation teams & $6 \%$ \\
\hline 4 & Volunteers & $43 \%$ \\
\hline
\end{tabular}

From the above table it is referred that about $43 \%$ of the respondents work as Volunteers.

Age of the respondents:

\begin{tabular}{|l|l|l|}
\hline Sl.No. & Age & Percentage \\
\hline 1 & $15-20 \mathrm{yrs}$ & $70 \%$ \\
\hline 2 & $21-25 \mathrm{yrs}$ & $10 \%$ \\
\hline 3 & $26-30 \mathrm{yrs}$ & $10 \%$ \\
\hline 4 & $31-35 \mathrm{yrs}$ & $5 \%$ \\
\hline 5 & Above $36 \mathrm{yrs}$ & $5 \%$ \\
\hline
\end{tabular}

From the above table it is inferred that about $70 \%$ of the respondents are in the age group $15-20$ yrs.

Education Qualification of the respondents:

\begin{tabular}{|l|l|l|}
\hline Sl.No. & Education & Percentage \\
\hline 1 & Below $10^{\text {th }}$ STD & Nil \\
\hline 2 & $10^{\text {th }}$ STD & $9 \%$ \\
\hline 3 & $12^{\text {th }}$ STD & $10 \%$ \\
\hline 4 & UG & $72 \%$ \\
\hline 5 & PG & $9 \%$ \\
\hline
\end{tabular}

From the above table it is inferred that about $72 \%$ respondent's education qualification is UG. 
DOI: $10.17148 /$ IARJSET.2021.8838

Income of the respondents:

\begin{tabular}{|l|l|l|}
\hline Sl.No. & Income & Percentage \\
\hline 1 & Rs.6000 - Rs. 15000 & $48 \%$ \\
\hline 2 & Rs.16000 - Rs.25000 & $23 \%$ \\
\hline 3 & Rs.26000 - Rs.35000 & $20 \%$ \\
\hline 4 & Above Rs.35000 & $9 \%$ \\
\hline
\end{tabular}

From the above table it is inferred that about $48 \%$ respondent's income are between Rs. 6000 - Rs. 15000.

Gender of the respondents:

\begin{tabular}{|l|l|l|}
\hline SI.No. & Gender & Percentage \\
\hline 1 & Male & $57 \%$ \\
\hline 2 & Female & $43 \%$ \\
\hline
\end{tabular}

From the above table it is inferred that majority of the respondents are male.

\section{WAYS TO ENGAGE FRONTLINE EMPLOYEES DURING COVID - 19}

A. Staying Connected with the help of technology

\begin{tabular}{|l|l|l|}
\hline Sl.No. & Particulars & Percentage \\
\hline 1 & Strongly Agree & $52 \%$ \\
\hline 2 & Agree & $41 \%$ \\
\hline 3 & Neutral & $5 \%$ \\
\hline 4 & Disagree & $2 \%$ \\
\hline 5 & Strongly Disagree & Nil \\
\hline
\end{tabular}

From the above table it is inferred that majority of the respondents prefer to stay connected with the help of technology. B. Empowering with digital tools

\begin{tabular}{|l|l|l|}
\hline Sl.No. & Particulars & Percentage \\
\hline 1 & Strongly Agree & $27 \%$ \\
\hline 2 & Agree & $66 \%$ \\
\hline 3 & Neutral & $5 \%$ \\
\hline 4 & Disagree & Nil \\
\hline 5 & Strongly Disagree & Nil \\
\hline
\end{tabular}

From the above table it is inferred that majority of the respondents prefer to empower with digital tools.

C. On-the-job training, and certifications

\begin{tabular}{|l|l|l|}
\hline Sl.No. & Particulars & Percentage \\
\hline 1 & Strongly Agree & $32 \%$ \\
\hline 2 & Agree & $59 \%$ \\
\hline 3 & Neutral & $9 \%$ \\
\hline 4 & Disagree & Nil \\
\hline 5 & Strongly Disagree & Nil \\
\hline
\end{tabular}

From the above table it is inferred that majority of the respondents prefer on - the - job training and certificate programs.

D. Boosting with reward and recognition

\begin{tabular}{|l|l|l|}
\hline Sl.No. & Particulars & Percentage \\
\hline 1 & Strongly Agree & $36 \%$ \\
\hline 2 & Agree & $59 \%$ \\
\hline 3 & Neutral & $5 \%$ \\
\hline 4 & Disagree & Nil \\
\hline 5 & Strongly Disagree & Nil \\
\hline
\end{tabular}

From the above table it is inferred that majority of the respondents prefer boosting them with reward and recognition. 


\section{International Advanced Research Journal in Science, Engineering and Technology}

Vol. 8, Issue 8, August 2021

DOI: $10.17148 /$ IARJSET.2021.8838

\section{E. Providing growth opportunities}

\begin{tabular}{|l|l|l|}
\hline Sl.No. & Particulars & Percentage \\
\hline 1 & Strongly Agree & $43 \%$ \\
\hline 2 & Agree & $48 \%$ \\
\hline 3 & Neutral & $9 \%$ \\
\hline 4 & Disagree & Nil \\
\hline 5 & Strongly Disagree & Nil \\
\hline
\end{tabular}

From the above table it is inferred that majority of the respondents prefer growth opportunities in the organization. F. Getting feedback regularly

\begin{tabular}{|l|l|l|}
\hline Sl.No. & Particulars & Percentage \\
\hline 1 & Strongly Agree & $32 \%$ \\
\hline 2 & Agree & $61 \%$ \\
\hline 3 & Neutral & $5 \%$ \\
\hline 4 & Disagree & Nil \\
\hline 5 & Strongly Disagree & $1 \%$ \\
\hline
\end{tabular}

From the above table it is inferred that majority of the respondents prefer getting feedback regularly.

V. Benefits in engaging frontline employees during Covid -19

SA - Strongly Agree, A - Agree, N - Neutral, D - Disagree, SD - Strongly disagree

\begin{tabular}{|l|l|l|l|l|l|l|}
\hline S.No. & Particulars & SA & A & N & D & SD \\
\hline $\mathbf{1}$ & $\begin{array}{l}\text { Helps to retain in the } \\
\text { organization }\end{array}$ & 32 & 64 & 4 & - \\
\hline $\mathbf{2}$ & $\begin{array}{l}\text { Helps to improve mental } \\
\text { health and well being }\end{array}$ & 29 & 60 & 9 & 2 & - \\
\hline $\mathbf{3}$ & Improve performance & 36 & 52 & 13 & - & - \\
\hline $\mathbf{4}$ & Helps to satisfy the customers & 36 & 50 & 11 & 2 & 2 \\
\hline $\mathbf{5}$ & Increase motivation & 38 & 52 & 9 & - & 2 \\
\hline $\mathbf{6}$ & Helps to increase the profit & 29 & 57 & 11 & 2 & 2 \\
\hline
\end{tabular}

From the above table it is inferred that engaging frontline employees leads to high retention, improved mental health and being, Improved performance, Satisfied customers and increased profit.

\section{CHI- SQUARE TEST:}

In which platform you work? * Income Crosstabulation

$\mathrm{H} 0$ - There is no significant relationship between platform they work and income

$\mathrm{H} 1$ - There is significant relationship between platform they work and income

\begin{tabular}{|c|c|c|c|c|c|c|}
\hline \multicolumn{7}{|c|}{ In which platform you work? * Income Crosstabulation } \\
\hline \multicolumn{7}{|l|}{ Count } \\
\hline & & \multicolumn{4}{|c|}{ Income } & \multirow[b]{2}{*}{ Total } \\
\hline & & $\begin{array}{l}6000- \\
15000 \\
\end{array}$ & $\begin{array}{l}16000- \\
25000 \\
\end{array}$ & $\begin{array}{l}26000- \\
35000\end{array}$ & $\begin{array}{l}\text { Above } \\
35000\end{array}$ & \\
\hline \multirow{4}{*}{$\begin{array}{l}\text { In which platform } \\
\text { you work? }\end{array}$} & Health care & 5 & 7 & 5 & 0 & 17 \\
\hline & $\begin{array}{l}\text { Essential Service } \\
\text { Provider }\end{array}$ & 8 & 2 & 1 & 1 & 12 \\
\hline & Sanitation Team & 1 & 3 & 3 & 0 & 7 \\
\hline & Volunteers & 13 & 5 & 2 & 4 & 24 \\
\hline \multicolumn{2}{|l|}{ Total } & 27 & 17 & 11 & 5 & 60 \\
\hline
\end{tabular}




\section{International Advanced Research Journal in Science, Engineering and Technology}

Vol. 8, Issue 8, August 2021

DOI: $10.17148 /$ IARJSET.2021.8838

\begin{tabular}{|l|r|r|r|}
\hline \multicolumn{3}{|c|}{ Chi-Square Tests } \\
& \multicolumn{1}{|c|}{ Value } & df & $\begin{array}{c}\text { Asymptotic } \\
\text { Significance (2- } \\
\text { sided) }\end{array}$ \\
\hline Pearson Chi-Square & $16.047^{\mathrm{a}}$ & 9 & .066 \\
\hline Likelihood Ratio & 17.717 & 9 & .039 \\
\hline Linear-by-Linear Association & .000 & 1 & .983 \\
\hline N of Valid Cases & 60 & & \\
\hline $\begin{array}{l}\text { a. 12 cells (75.0\%) have expected count less than 5. The minimum } \\
\text { expected count is .58. }\end{array}$
\end{tabular}

Since the significance value is greater than 0.05 , null hypothesis is accepted. There is no significant relationship between platform they work and income.

\section{CONCLUSION:}

From the above study it is significantly concluded that staying connecting with technology, empowering digital tools, on the job training, boosting with reward and recognition, providing opportunities and getting feedback regularly helps to improve the employee engagement among the frontline employees during Covid - 19. It is also suggested that organizations shall concentrate on providing health benefits, Insurance policies for better engagement. It is also concluded that engaging frontline employees provides better retention, improve mental performance, increase motivation and helps to improve organization's profit.

\section{REFERENCES:}

1. Macey, W. H., \& Schneider, B. (2008). The meaning of employee engagement. Industrial and organizational Psychology, 1(1), 3-30.

2. Saks, A. M., \& Gruman, J. A. (2014). What do we really know about employee engagement?. Human resource development quarterly, 25(2), $155-182$

3. Albrech, S. L. (2011). Handbook of employee engagement: Perspectives, issues, research and practice. Human Resource Management International Digest.

4. Markos, S., \& Sridevi, M. S. (2010). Employee engagement: The key to improving performance. International journal of business and management, 5(12), 89

5. Kular, S., Gatenby, M., Rees, C., Soane, E., \& Truss, K. (2008). Employee engagement: A literature review.

6. Menonjyoti Kalita; Golam Imran Hussain. "Determining the Influencing Factors of COVID 19 on Mental Health Using Neural Network". International Research Journal on Advanced Science Hub, 3, Special Issue 6S, 2021, 126-129.

7. Yeshi Ngima; Dorjee Tsering. "Impact of COVID-19 on Education". International Research Journal on Advanced Science Hub, 2, Special Issue ICAMET 10S, 2020, 34-39. doi: 10.47392/irjash.2020.196 